\title{
Changes to structural solutions and their effect on radon functionality on the structures base on the ground
}

\author{
Ari-Veikko Kettunen ${ }^{1, *}$ \\ ${ }^{1}$ Vahanen Building Physics Ltd, Linnoitustie 502600 Espoo, Finland
}

\begin{abstract}
The structural design in terms of radon of the ground-supported base floor solutions currently used in Finland are largely based on the extensive measurements conducted in the 1980s and the 1990s. In addition to ventilating/underpressurising the base of the building, the instructions in Finland and other European countries i.e. Denmark [1] focus on the adequate sealing of the base floor structure in order to prevent the air containing radon from the soil from entering the rooms at harmful levels with air flows. According to the Finnish radon guidelines, the transmission of radon by means of diffusion is prevented by using a sufficiently thick concrete slab. The structural solutions used in base floors have, however, developed significantly over the decades. The thickness of thermal insulation of a ground-supported base floor slab has been increased significantly especially due to reasons related to the conservation of energy. In the 1980s, the polystyrene layer in the base floor was $50 \ldots 100 \mathrm{~mm}$, whereas it currently is $200 \mathrm{~mm}$. This change reduces the ground temperature under the thermal insulation, thereby also reducing the moisture diffusion flow from the ground to the concrete slab of the base floor. As a result, the current concrete slabs used in the base floor will be significantly drier than those of the 1980s after the construction humidity has dried. Underfloor heating, which is nowadays used in Finland very commonly, also impacts the moisture of the concrete slab by increasing the concrete slab's temperature and drying it further. The measurements now conducted on concrete have shown that the radon diffusion permeability of dry concrete ( $\mathrm{Rh}$ approximately $50 \%$ ) is so high that stopping the radon diffusion flow solely by means of an 80 -mm concrete slab may not be an adequate solution in some cases.
\end{abstract}

\section{Diffusion of radon in ground- supported base floor structures}

In the $1980 \mathrm{~s}$, typically $50 \ldots 100 \mathrm{~mm}$ of polystyrene thermal insulation was placed under the concrete slab in a ground-supported base floor of Finnish detached houses, and underfloor heating was not that customary yet. The thermal insulation regulations applicable to structures have changed over the decades, and according to the current regulations, a minimum $200 \mathrm{~mm}$ of thermal insulation is often placed under the concrete slab. Detached houses also have underfloor heating almost without exception. As a result of these changes, the humidity of the concrete base floor slab after the drying of humidity resulting from the construction is significantly lower than in the solutions used in the 1980s. In the 1980s solutions, the humidity of concrete at equilibrium could easily reach $70 . .75 \mathrm{Rh} \%$, whereas in the current solutions, the humidity of concrete may be less than $50 \mathrm{Rh} \%$ after the construction humidity has dried. The change in the thermal functioning of the structure therefore has an effect on its humidity properties, which in turn has an effect on the functionality of the structure in terms of radon, see figure 1 .

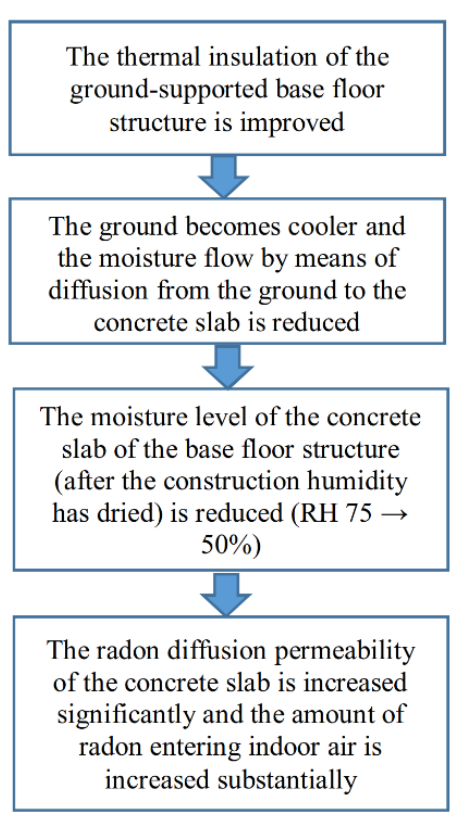

Fig. 1. The impact of the changed base floor structure on the amount of radon entering indoor air by means of diffusion. 
In addition to the cooling of the ground as shown in figure 1 , the increased temperature of the concrete slab resulting from underfloor heating reduces the moisture level of the concrete. The capillary break layers and underdrain solutions under the floor are also currently designed and implemented much better than in the 1980s, which reduces the moisture level of the capillary break layer and, at the same time, of the concrete slab. Instead of plastic carpeting, also coating materials not attached to the substrate as well as ceramic tiles are used widely in detached houses, allowing better drying of the concrete slab.

\subsection{Measurement method used}

The measurements were conducted at Vahanen Building Physics Ltd's laboratory using a method developed for the measurement of radon diffusion permeability based on the radon diffusion permeability measurement equipment developed at Helsinki University of Technology in the 1980s (see figure 2) as well as the principle of standard EN DIN ISO 11665-10 (VDE 0493-1-6660):2013-08 [3].

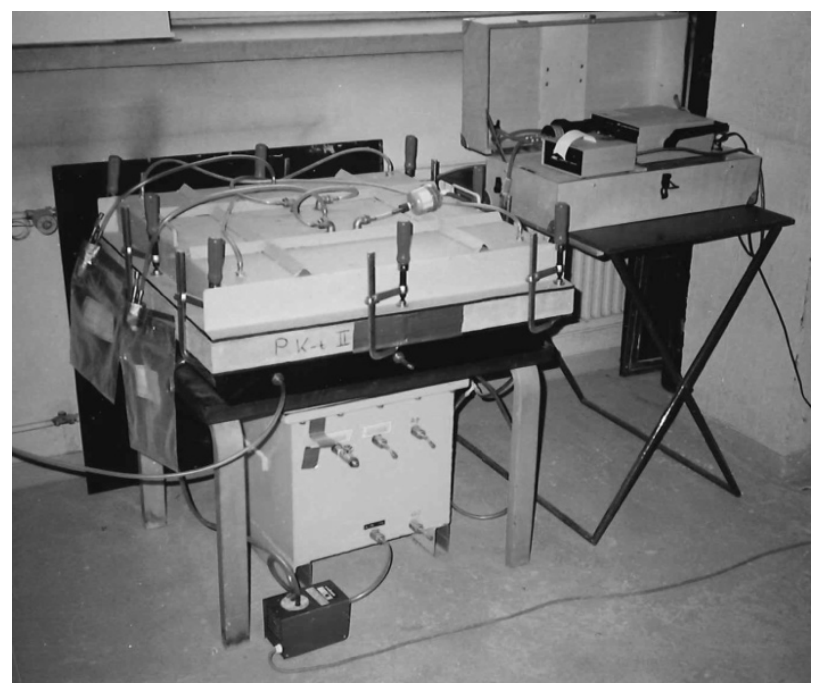

Fig. 2. Measurement equipment used in the test in 1989. The source of radon was sand containing radium [2].

\subsection{Measurement arrangement}

The equipment shown in figure 3 was developed for the measurement of radon diffusion. Rocks containing radon were used as radon sources in the bottom chamber, creating a maximum radon level of approximately $2,000,000 \mathrm{~Bq} / \mathrm{m} 3$ in the sealed steel chamber. The radon levels were measured using the AlphaGuard DF2000 radon monitor. The tightness of the system was confirmed by means of triple sealing: two different sealing compounds and aluminium tape used at the edges. Tightness was tested by means of pressure tests and a tracergas.

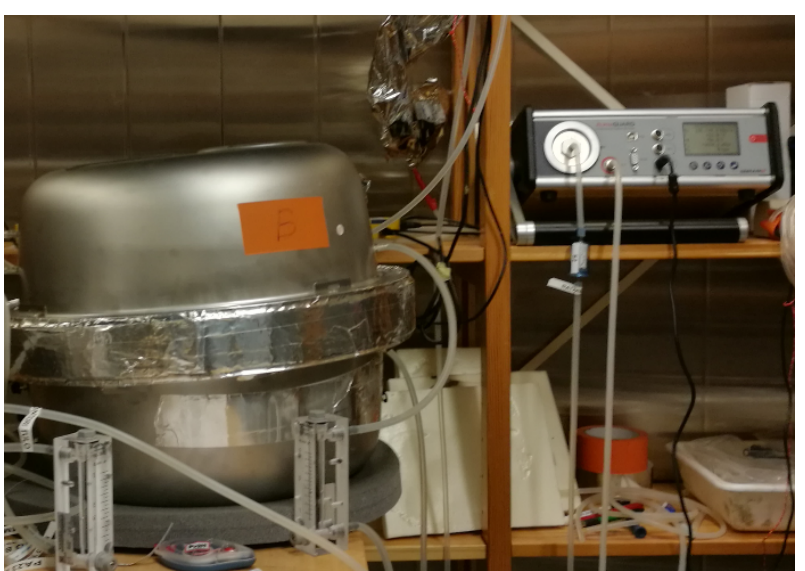

Fig. 3. Measurement equipment used in the study. The figure shows the measurement chambers on the left, the material being studied between the chambers and the radon monitor AlphaGuard DF2000 at the top right.

\subsection{Materials to be examined}

The material to be examined tried to imitate the concrete used in the 1980s to allow the comparison of results from different ages. The target strength of the concrete to be examined was $\mathrm{K} 20$, its water-cement ratio 0.86 and maximum aggregate grain size $10 \mathrm{~mm}$. The concrete mix to be examined was subjected to compression strengths, and the compression strength of the concrete was 20.1 $\mathrm{MN} / \mathrm{m}^{2}$ at 28 days. In addition, several different coating materials, films placed on the slab and manually applied products were examined.

\subsection{Measurement results}

Two test pieces, A and B, were made of the concrete, and their radon diffusion permeability was measured twice. Table 1 shows the measurement results. The relative humidity in the concrete's pore air was approximately $50 \%$ at the time of measurement throughout the slab thickness.

Table 1. Radon diffusion coefficients of the concrete slabs examined. The relative humidity in the concrete's pore air was approximately $50 \%$ [4].

\begin{tabular}{|c|c|}
\hline $\begin{array}{c}\text { Test piece and } \\
\text { measurement }\end{array}$ & $\begin{array}{c}\text { Diffusion coefficient } \\
{[\mathbf{m} \mathbf{2} / \mathbf{h}]}\end{array}$ \\
\hline A1 & 0.000653 \\
\hline A2 & 0.000632 \\
\hline B1 & 0.000588 \\
\hline B2 & 0.000620 \\
\hline Average & 0.000624 \\
\hline
\end{tabular}


The radon diffusion coefficient in concrete used as the basis for the Finnish radon guidelines in the 1980s was approximately $0.00013 \mathrm{~m}^{2} / \mathrm{h}$ when the relative humidity in the concrete's pore air was approximately $72 . .74 \%$, or approximately one fifth of the radon diffusion coefficient of concrete measured now at approximately $50 \% \mathrm{Rh}$. Of the coating materials studied, the product applied manually on the slab had the best radon diffusion coefficient $2.2 \mathrm{E}-08\left[\mathrm{~m}^{2} / \mathrm{h}\right]$.

\section{Analysis of the effect of radon diffusion on indoor radon concentration}

The radon diffusion permeabilities obtained from the test were used in the calculation of radon level in indoor air for the radon diffusing through the base floor, see figure 4. The calculation assumes that the base floor structure contains only the structural layers mentioned in the picture. The building has one floor and the room height is $2.5 \mathrm{~m}$, and the indoor ventilation efficiency is $0.51 / \mathrm{h}$.

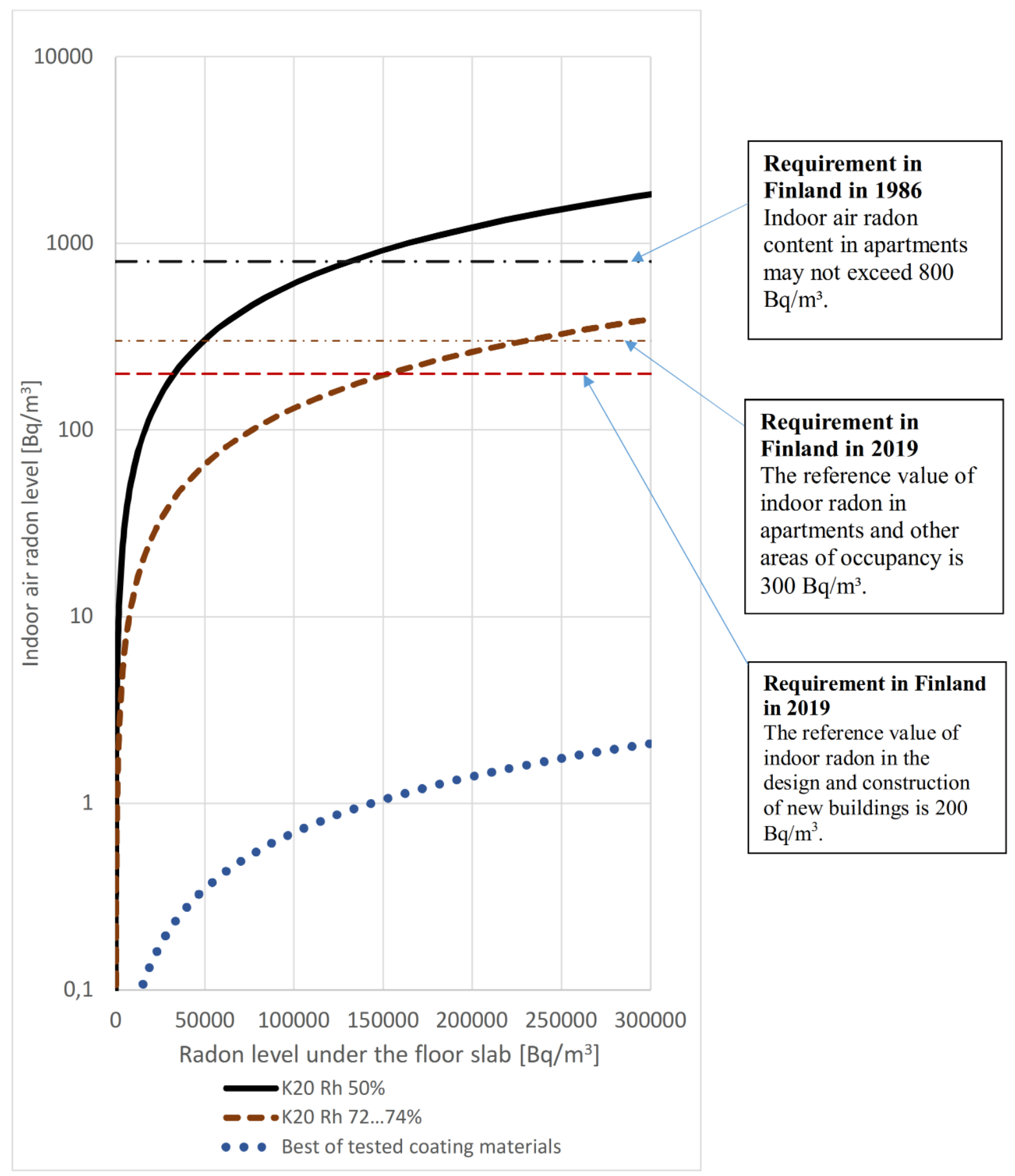

Fig. 4. The indoor air radon level caused by radon diffusing through the floor slab at indoor ventilation efficiency $0.51 / \mathrm{h}$ for various radon levels under the floor slab. The radon diffusion coefficient value measured in the 1980s has been used for concrete K20 Rh $72 . .74 \%$. 
The radon level in the pore air of gravel under the floor varies greatly in Finnish radon-containing regions. The radon levels are very commonly tens of thousands of $\mathrm{Bq} / \mathrm{m}^{3}$, see figure 5 , and the worst levels are up to hundreds of thousands of $\mathrm{Bq} / \mathrm{m}^{3}$.

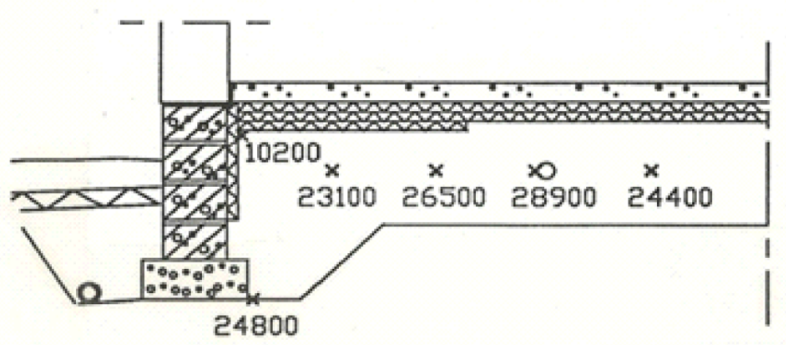

Fig. 5. An example of the radon level distribution $\left[\mathrm{Bq} / \mathrm{m}^{3}\right]$ in the gravel layer of the ground-supported base floor [5].

\section{Summary}

The role of radon diffusion is, as a rule, much smaller than that of soil gas penetration through shrinkage cracks, cracks and unforeseen openings by infiltration. By carefully following the instructions for sealing structures and using tracer gas technology to ensure the quality of the work, almost complete airtightness can be achieved. But at least in Finland, there are areas where the soil radon concentration is so high that the role of diffusion could become significant.

The practical situation develops gradually when construction humidity dries from the base floor structures constructed according to the new Finnish guidelines and the structure dry over the years. Indoor air radon levels are often measured soon after the completion of the building, and as a result, the increased radon diffusion slow due to the slow drying of the concrete slab may not be reflected in the measurements.

This may be a problem especially in ridge areas with high radon levels, when the radon ventilation system cannot reduce the radon levels of the underdrain gravel layer, emphasizing the impact of diffusion. The base floor slab may also reach a lower humidity than usual in the ridge areas. The measurement results raise the question whether the Finnish radon guidelines should be updated in terms of preventing the radon diffusion flow. Are additional structural layers needed in the base floor structure in addition to concrete to ensure that the indoor radon level is low enough? Tested products which prevent radon diffusion practically completely are available in the market.

The research was funded by Saint-Gobain Finland Oy, Weber. The support is gratefully acknowledged.

\section{References}

1. T. V. Rasmussen, Radonsikring af nye bygninger, SBi-anvisning 233, Statens Byggeforskningsinstitut, Aalborg Universitet, 56, (2015)

2. EN DIN ISO 11665-10 (VDE 0493-16660):2013-08 Measurement of radioactivity in the environment- Air: radon222-Part 10: Determination of the diffusion coefficient in waterproof materials using activity concentration measurement, (2013)

3. P. Kronqvist, Rakennusaineen radonin diffusioläpäisevyyden mittausmenetelmän kehittäminen. Espoo, Teknillinen korkeakoulu, Rakennus ja maanmittaustekniikan osasto,125, (1989)

4. Sisäilmastoseminaari 2020 SIY Raportti 38, (2020)

5. A-V. Kettunen, Alapohjan tuuletusjärjestelmän suunnittelu ja testaus kolmessa pientalokohteessa. Teknillinen korkeakoulu, Espoo 40, (1990) 